\title{
Estimation of Genetic Architecture in Agro-Morphological Traits of Garden Pea in Mid Hill Region of Uttarakhand, India
}

\author{
A. Kumar Singh ${ }^{1 *}$, A. Paliwal ${ }^{1}$, S. Chandra Pant ${ }^{1}$, P. Bahuguna ${ }^{1}$, \\ A. Bahadur ${ }^{2}$ and R. Bhalla ${ }^{1}$ \\ ${ }^{1}$ Department of vegetable science, VCSGUUHF Bharsar, Pauri Garhwal UK, India \\ ${ }^{2}$ Division of crop production IIVR Varanasi, India \\ *Corresponding author
}

\section{A B S T R A C T}

\section{Key words \\ Genetic variability, Heritability, Genotype, Diversity and Genetic gain \\ Article Info \\ Accepted: \\ 20 July 2018 \\ Available Online: \\ 10 August 2018}

\begin{abstract}
In order to appraise genetic parameters and variability in the crop, the information on the nature and degree of diversity in the genotypes is crucial. Thirty two genotypes along with two commercial varieties (PB-89 and SolanNirog) as check were evaluated for assessing genetic variability and heritability for seventeen different agro-morphological characters. The mean sums of squares due to genotype were highly significant for all of the characters. The estimates of GCV and PCV is highest values were shown by plant height, pod yield per plant \& pod yield per plots whereas moderate for dry matter content, No. of node per plant and 100 seed weight. High heritability estimates associated with high genetic gain for plant height, pod yield per plant and pod yield per plot reflecting the involvement of additive gene action suggesting more scope of selection of these traits.
\end{abstract}

\section{Introduction}

Pea (Pisum sativum L.) $2 \mathrm{n}=2 \mathrm{x}=14$ is one the most important legume crop of India, Based on genetic diversity, Central Asia, the Near East, Abyssinia and the Mediterranean have been recognized as centres of origin for pea (Gritton, 1980). Pea is rich source of different phyto-nutrients, minerals, vitamins and anti-oxidants benefiting for human health. Greens pods are excellent source of Folic acid, Ascorbic acid (Vitamin C) \& Vitamin K. It is grown at higher altitudes in tropics with temperatures from 7 to $30{ }^{\circ} \mathrm{C}$ (Duke, 1981). The overall yield of pea is low in India as compared to the world average yield due to the narrow genetic base and limited variability used in the development of local varieties (Kumar et al., 2004). Genetic variability plays an important role in a crop in selecting the best genotypes for making rapid improvement in yield and quality characters as well as to select the potential parent for hybridization programmes.

Heritability is an index for calculating the relative influence of environment on expression of genotypes. The selection for highly heritable characters is effective. Therefore, heritability along with other parameters of variability can be used in predicting the gain for a given selection 
intensity, Genetic divergence further gives an idea about the scope of improvement in a character through simple selection. But a considerable level of genetic variance among peas of diverse origin has also been reported by some breeders (Nisar et al., 2011). Therefore, continuous efforts are required to increase the production and productivity of pea using diverse and exotic sources. Crop improvement depends immensely on the availability of diverse materials and their judicial utilization. Therefore, present investigation was carried out to assess the genetic components and trait associations in diverse set of pea genotypes for their utilization in crop improvement programs.

\section{Materials and Methods}

The present investigation was carried out at the Demonstration and Research Block Department of Vegetable Science, College of Horticulture, Bharsar. VCSG Uttarakhand University of Horticulture and Forestry during kharif 2014.The site of experiment is located at latitude of $30.056^{\circ} \mathrm{N}$ and longitude $78.99^{\circ} \mathrm{E}$ and at an elevation of 1900-2200 meters above mean sea level. This region has falls in subhumid, sub-temperate and mid-hill zone of Uttarakhand. The maximum temperature during May-June is recorded between $30^{\circ} \mathrm{C}$ $35^{\circ} \mathrm{C}$ however, and nights are cool. December and January are the coldest months, the minimum temperature reaches to $1^{0} \mathrm{C}$ to $-4{ }^{0} \mathrm{C}$. Relative humidity is normally highest during rainy season (July-August) often recorded near to saturation point $(92-97 \%)$. The soil textural class at the site was sandy loam. The experimental material comprised of a 32 promising genotypes including with two checks 'PB-89' and 'SolanNirog' in RCBD with three replications. The net plot size was $1.22 \mathrm{~m}^{2}$ with spacing $30 \mathrm{~cm}$ row to row and 10 $\mathrm{cm}$ plant to plant. The recommended package of practices was followed to raise the healthy crop. After eliminating the border plants, observations were recorded on five randomly chosen plants for 17 quantitative traits viz. Days to 50 per cent germination, Days to 50 per cent flowering, Number of cluster per plant, Plant height $(\mathrm{cm})$, Number of branch per plant, Intermodal length, Number of node per plant, Number of pods per plant, Number of seed per pod, pods length, Per cent dry matter (\%), Days to harvesting maturity, 100seed weight, Yield per plant, Yield per plots and Harvest index.

The statistical analysis was carried out for each observed character under the study using MS-Excel, SPSS 16.0 and SPAR 2.0 packages. The mean values of data were subjected to analysis of variance and ANOVA was set as per Gomez et al., (1983) for Randomized Block Design.

\section{Results and Discussion}

The mean sum square shows the highly significant differences among the genotypes for all the traits under study, which revealed the existence of good amount of variability in the germplasms and suggested that the experimental materials were genetically divergent (Table 1). This indicates that there is plentiful scope for selection of promising lines from the present gene pool for yield and yield contributing traits. Table 2 exist the mean performance of 32 genotypes along with two commercial checks for 17 agro-morphological traits along with coefficient of variation and critical difference. The assessment of genotypic coefficient of variation and phenotypic coefficient of variation is gave a clear cut picture of variations present in the available germplasms. Table 3 revealed that all the characters studied, phenotypic coefficients of variation were higher in magnitude than genotypic coefficients of variation, though difference was very less in most of the characters. This indicates that these traits are less influenced by 
environmental factors. Generally coefficients of variation were of higher to medium magnitude which further suggests that genetic diversity was present in the germplasms. These results get a support from the findings of Mehta et al., (2005) and Rai et al., (2006). The phenotypic coefficients of variation (PCV) were found high gain for plant height, pod yield per plant, pod yield per plot, number of pods per plant, number of cluster per plant, number of branch per plant, $50 \%$ germination, internode length and harvest index.

This shows greater genetic variability among all the genotypes for these characters. Moderate phenotypic coefficients of variation $(\mathrm{PCV})$ were found for dry matter content, number of node per plant, 100 seed weight, days to $50 \%$ flowering, shelling percentage, number of seed per pod, pod length and days to maturity. These results also supported with the findings of Saxesena et al., (2014)
Similarly, the genotypic coefficients of variation (GCV) were high for plant height, pod yield per plant, pod yield per plot, number of pods per plant, number of cluster per plant, number of branch per plant, $50 \%$ germination and internode length whereas, moderate genotypic coefficients of variation (GCV) were recorded for, harvest index number of branch per plant, 100 seed weight, days to 50 $\%$ flowering, number of node per plant, dry matter content, pod length, days to maturity shelling percentage and 100 seed weight. Similar results for different characters have also been reported by Kosev et al., (2015).

Heritability is good index for transmission of character from parent to their offspring. The estimates of heritability help the plant breeder in selection of elite genotypes from diverse genetic populations. It determines the amount of genetic variance to total phenotypic variance.

Table.1 Analysis of variance for different agro-morphological traits in garden pea

\begin{tabular}{|l|l|l|}
\hline Character & Treatment (d. f $=31)$ & CV \% \\
\hline Days to 50\% germination (number) & $40.548^{* * *}$ & 12.424 \\
\hline Days to 50\% flowering (number) & $226.46^{* * * *}$ & 5.290 \\
\hline Number of pods per plant & $106.360^{* *}$ & 27.109 \\
\hline Pod length (cm) & $2.965^{* * *}$ & 4.319 \\
\hline Number of seeds per pod & $1.881^{* *}$ & 7.952 \\
\hline Number of cluster per plant & $52.576^{* *}$ & 27.925 \\
\hline Number of branch per plant & $0.845^{* * *}$ & 23.841 \\
\hline Number of node per plant & $23.619^{* * *}$ & 12.545 \\
\hline Inter node length & $11.190^{* *}$ & 13.830 \\
\hline Plant height (cm) & $6,338.353^{* *}$ & 20.215 \\
\hline Yield per plant (g) & $1,524.402^{* *}$ & 25.633 \\
\hline Yield per plots (kg) & $2.369^{* * * *}$ & 25.548 \\
\hline 100 seed weight & $38.689^{* * * *}$ & 9.136 \\
\hline Dry matter content (\%) & $178.702^{* *}$ & 14.994 \\
\hline Shelling per cent & $76.781^{* * *}$ & 9.673 \\
\hline Harvest index & $218.808^{* * *}$ & 14.818 \\
\hline Days to harvesting maturity & $842.863^{* *}$ & 1.942 \\
\hline
\end{tabular}

**Significant at 1 
Table.2 Mean performance for different agro-morphological characters in garden pea

\begin{tabular}{|c|c|c|c|c|c|c|c|c|c|c|c|c|c|c|c|c|c|}
\hline Genotype & DG & DF & NPP & PL (cm) & NSP & NCP & NBP & NNP & IL & PH (cm) & $\mathbf{Y P} \mathbf{P}_{1}(\mathbf{g})$ & $\mathbf{Y P}_{2}(\mathrm{~kg})$ & 100SW (g) & DMC (\%) & SP & HI & DHM \\
\hline ArkaAjit & 14.333 & 41.000 & 27.400 & 8.173 & 7.000 & 17.867 & 3.267 & 17.733 & 6.553 & 102.367 & 70.005 & 2.797 & 28.867 & 46.500 & 50.090 & 39.067 & 151.000 \\
\hline ArkaKarthika & 11.333 & 57.333 & 23.467 & 10.060 & 8.267 & 16.867 & 2.400 & 21.133 & 9.733 & 114.500 & 69.311 & 2.767 & 25.033 & 43.877 & 32.530 & 34.623 & 177.667 \\
\hline ArkaSampurna & 14.333 & 59.000 & 9.467 & 8.780 & 6.733 & 7.667 & 3.000 & 14.467 & 6.053 & 67.733 & 48.873 & 1.950 & 23.967 & 36.723 & 40.517 & 47.833 & 182.000 \\
\hline PC-531 & 14.667 & 58.333 & 10.000 & 10.187 & 8.533 & 9.333 & 1.867 & 15.267 & 9.473 & 105.160 & 47.622 & 1.900 & 20.327 & 49.027 & 42.717 & 44.763 & 162.333 \\
\hline PB-89* & 16.667 & 41.667 & 11.133 & 10.307 & 9.000 & 7.667 & 1.867 & 15.467 & 8.187 & 72.953 & 61.923 & 2.472 & 16.267 & 40.327 & 47.750 & 69.363 & 134.333 \\
\hline SolanNirog* & 16.667 & 55.000 & 17.600 & 6.743 & 6.533 & 16.400 & 2.600 & 20.600 & 11.020 & 205.767 & 48.683 & 1.946 & 21.967 & 41.703 & 35.777 & 43.570 & 161.667 \\
\hline CHP-2 & 19.333 & 65.667 & 11.467 & 8.407 & 6.333 & 9.600 & 2.683 & 19.067 & 7.987 & 90.300 & 38.842 & 1.790 & 20.167 & 46.417 & 48.580 & 38.240 & 177.667 \\
\hline Kashi Shakti & 17.333 & 50.667 & 15.400 & 10.453 & 8.867 & 12.067 & 2.417 & 16.667 & 11.280 & 116.467 & 67.854 & 2.710 & 20.233 & 61.677 & 35.593 & 41.637 & 147.667 \\
\hline KashiUdai & 13.667 & 38.333 & 12.100 & 9.467 & 7.733 & 11.000 & 1.800 & 15.000 & 8.187 & 96.800 & 78.139 & 3.122 & 22.633 & 48.313 & 33.630 & 54.870 & 122.000 \\
\hline AP-1 & 16.000 & 44.000 & 14.533 & 9.330 & 7.667 & 15.933 & 2.800 & 16.333 & 7.220 & 94.333 & 66.547 & 2.661 & 20.533 & 53.837 & 33.783 & 46.787 & 133.333 \\
\hline AP-3 & 11.667 & 46.667 & 16.667 & 9.047 & 7.467 & 14.600 & 2.467 & 19.067 & 8.570 & 118.433 & 73.023 & 2.921 & 18.900 & 43.823 & 45.287 & 44.220 & 150.000 \\
\hline AP-4 & 18.000 & 60.000 & 17.533 & 7.558 & 6.267 & 11.667 & 2.550 & 17.100 & 7.193 & 98.393 & 70.366 & 2.814 & 24.567 & 50.707 & 34.927 & 37.613 & 172.333 \\
\hline Arkel & 11.667 & 40.667 & 20.733 & 9.120 & 7.600 & 12.667 & 2.367 & 17.250 & 7.513 & 87.673 & 119.475 & 4.778 & 25.567 & 44.687 & 40.383 & 55.937 & 120.000 \\
\hline BP-801 & 22.667 & 55.000 & 17.267 & 9.038 & 7.867 & 15.867 & 2.867 & 17.667 & 9.527 & 102.000 & 76.780 & 3.071 & 24.600 & 55.553 & 44.473 & 43.720 & 132.333 \\
\hline VL-7 & 20.333 & 47.667 & 12.200 & 8.537 & 6.600 & 10.200 & 2.800 & 17.333 & 10.080 & 103.167 & 73.100 & 2.924 & 24.633 & 41.537 & 40.603 & 44.943 & 137.667 \\
\hline VL-12 & 17.333 & 65.667 & 14.067 & 7.360 & 6.667 & 14.333 & 2.133 & 19.333 & 11.627 & 162.667 & 38.930 & 1.556 & 15.033 & 59.330 & 39.180 & 32.517 & 147.667 \\
\hline Pant Pea -74 & 18.667 & 60.000 & 34.600 & 7.289 & 6.600 & 21.933 & 3.756 & 19.667 & 9.853 & 124.200 & 86.869 & 3.474 & 23.233 & 55.120 & 42.783 & 43.760 & 147.667 \\
\hline PSM-5 & 12.333 & 46.667 & 24.067 & 8.923 & 7.533 & 19.133 & 2.867 & 18.867 & 9.967 & 110.870 & 128.330 & 5.133 & 22.933 & 45.143 & 45.160 & 64.693 & 134.333 \\
\hline Pant Pea-13 & 23.333 & 55.667 & 21.133 & 7.247 & 7.067 & 19.350 & 2.400 & 21.267 & 9.093 & 99.420 & 54.833 & 2.193 & 27.267 & 55.067 & 40.817 & 39.897 & 162.667 \\
\hline Pant Pea-14 & 23.667 & 60.000 & 19.333 & 8.207 & 7.267 & 12.933 & 2.533 & 20.333 & 8.920 & 122.456 & 54.080 & 2.163 & 26.233 & 72.577 & 50.023 & 37.763 & 177.667 \\
\hline Pant Pea-86 & 18.667 & 58.333 & 17.267 & 7.640 & 6.667 & 14.200 & 2.533 & 22.400 & 11.567 & 212.275 & 57.909 & 2.316 & 15.133 & 50.537 & 40.640 & 39.573 & 147.667 \\
\hline Pant Pea-96 & 24.667 & 55.667 & 28.467 & 8.133 & 7.667 & 19.800 & 2.933 & 18.667 & 14.327 & 225.000 & 63.513 & 2.540 & 19.200 & 59.670 & 36.943 & 37.820 & 163.333 \\
\hline Pant Pea-25 & 14.000 & 55.000 & 20.333 & 6.993 & 7.533 & 15.333 & 2.600 & 19.333 & 8.860 & 99.400 & 58.173 & 2.327 & 14.900 & 54.507 & 44.493 & 46.103 & 163.667 \\
\hline Pant Pea-155 & 15.000 & 56.667 & 20.000 & 7.439 & 6.533 & 16.133 & 3.333 & 19.400 & 9.748 & 118.400 & 71.385 & 2.855 & 21.000 & 53.350 & 34.187 & 43.110 & 149.000 \\
\hline Pant Uphar & 12.667 & 56.667 & 13.067 & 7.947 & 6.267 & 16.400 & 1.600 & 22.067 & 9.753 & 115.067 & 59.547 & 2.381 & 20.880 & 60.473 & 34.580 & 43.987 & 151.000 \\
\hline PalamSumul & 16.333 & 65.000 & 12.600 & 7.713 & 7.133 & 8.389 & 1.889 & 14.333 & 6.573 & 67.444 & 46.408 & 1.856 & 20.967 & 56.600 & 39.817 & 38.880 & 137.667 \\
\hline PalamPriya & 15.000 & 60.000 & 12.267 & 8.260 & 7.667 & 8.267 & 1.900 & 16.217 & 5.880 & 56.359 & 25.150 & 1.005 & 17.633 & 45.033 & 44.030 & 36.027 & 144.000 \\
\hline PalamTriloki & 11.000 & 48.000 & 12.600 & 8.975 & 9.000 & 4.133 & 1.467 & 10.333 & 6.031 & 47.523 & 36.949 & 1.477 & 24.633 & 47.033 & 45.680 & 60.350 & 122.000 \\
\hline DPP- 3 & 14.000 & 70.000 & 25.933 & 8.387 & 8.200 & 16.800 & 2.867 & 22.133 & 10.507 & 225.230 & 60.260 & 2.410 & 18.500 & 43.977 & 40.980 & 43.397 & 153.000 \\
\hline DPPM- 65 & 17.333 & 66.667 & 14.933 & 8.220 & 6.733 & 16.924 & 2.200 & 22.133 & 6.820 & 119.787 & 39.173 & 1.567 & 18.870 & 48.420 & 38.467 & 39.587 & 160.667 \\
\hline PPC- 66 & 14.000 & 65.000 & 14.200 & 9.660 & 7.400 & 11.083 & 2.200 & 18.933 & 7.433 & 63.441 & 26.927 & 1.077 & 19.360 & 42.163 & 46.000 & 34.870 & 158.667 \\
\hline DPP- 1526 P & 15.667 & 68.000 & 15.467 & 8.573 & 7.067 & 12.133 & 1.733 & 21.933 & 8.600 & 87.067 & 36.700 & 1.668 & 19.867 & 43.930 & 45.103 & 45.883 & 151.000 \\
\hline $\mathrm{SE}(\mathrm{m}) \pm$ & 1.171 & 1.693 & 3.855 & 0.212 & 0.338 & 2.200 & 0.339 & 1.330 & 0.709 & 13.249 & 9.044 & 0.362 & 1.127 & 4.322 & 2.296 & 3.784 & 1.693 \\
\hline $\mathrm{SE}(\mathrm{d}) \pm$ & 1.656 & 2.394 & 2.726 & 0.300 & 0.478 & 3.111 & 0.479 & 1.881 & 1.003 & 18.737 & 12.791 & 0.512 & 1.594 & 6.112 & 3.247 & 5.351 & 2.395 \\
\hline C.D. $0.05 \%$ & 3.318 & 4.798 & 7.724 & 0.601 & 0.957 & 6.235 & 0.959 & 3.768 & 2.009 & 37.546 & 25.630 & 1.027 & 3.194 & 12.248 & 6.506 & 10.723 & 4.799 \\
\hline
\end{tabular}

*Check cultivar

Where, DG=Days to $50 \%$ germination, $\mathrm{DF}=$ Days to $50 \%$ flowering, NNP=Number of nods per plant, $\mathrm{NCP}=\mathrm{Number}$ of cluster per plant, $\mathrm{NBP}=\mathrm{Number}$ of branch per plant, $\mathrm{IL}=$ Internode length, NPP=Number of pods per plant, $\mathrm{PL}=\mathrm{Pod}$ length, NSP=Number of seeds per pod, $\mathrm{SP}=\mathrm{Shelling}$ percentage, $\mathrm{PH}=\mathrm{Plant}$ height, $\mathrm{DM}=$ Days to maturity, $\mathrm{HI}=$ Harvesting index, $\mathrm{DMC}=$ Dry matter content, $\mathrm{YP}_{1}=$ yield per plant, $\mathrm{YP}_{2}=y i e l d$ per plot, $\mathrm{SI}=\mathrm{Seed}$ index $(100 \mathrm{seed}$ weight $)$ 
Table.3 Range, mean, PCV, GCV, heritability and genetic gain for different traits in garden pea

\begin{tabular}{|c|c|c|c|c|c|c|c|c|}
\hline \multirow[t]{2}{*}{$\begin{array}{l}\text { Sr. } \\
\text { No. }\end{array}$} & \multirow[t]{2}{*}{ Characters } & \multirow[t]{2}{*}{ Range } & \multirow[t]{2}{*}{$\begin{array}{l}\text { Mean } \pm \\
\operatorname{SE}(m)\end{array}$} & \multicolumn{2}{|c|}{$\begin{array}{c}\text { Coefficients of Variation } \\
(\%)\end{array}$} & \multirow[t]{2}{*}{$\begin{array}{l}\text { Heritability } \\
(\%)\end{array}$} & \multirow[t]{2}{*}{$\begin{array}{l}\text { Genetic } \\
\text { Gain }(\%)\end{array}$} & \multirow[t]{2}{*}{$\begin{array}{l}\text { Genetic } \\
\text { Advance }\end{array}$} \\
\hline & & & & Phenotypic & Genotypic & & & \\
\hline 1. & Days to $50 \%$ flowering & $38.33-70.0$ & $55.43 \pm 1.693$ & 16.26 & 15.37 & 89.4 & 0.29 & 16.60 \\
\hline 2. & Number of pods per plant & $9.47-34.60$ & $17.41 \pm 2.726$ & 40.73 & 30.40 & 55.7 & 46.75 & 8.14 \\
\hline 3. & Shelling percentage $(\%)$ & $32.53-50.09$ & $41.11 \pm 2.296$ & 14.62 & 10.97 & 56.2 & 16.93 & 6.96 \\
\hline 4. & Dry matter content $(\%)$ & $36.72-72.58$ & $49.92 \pm 4.322$ & 19.72 & 12.81 & 42.2 & 17.14 & 8.56 \\
\hline 5. & 100 seed weight(g) & $14.90-28.87$ & $21.37 \pm 1.127$ & 18.38 & 15.95 & 75.3 & 28.54 & 6.10 \\
\hline 6. & Harvest index (\%) & $32.52-69.36$ & $44.23 \pm 3.784$ & 22.79 & 17.31 & 57.7 & 27.08 & 11.98 \\
\hline 7. & Plant height (cm) & $47.52-225.23$ & $113.52 \pm 13.249$ & 43.73 & 38.77 & 78.6 & 70.82 & 80.40 \\
\hline 8. & Number of branch per plant & $1.47-3.76$ & $2.45 \pm 0.339$ & 29.07 & 16.63 & 32.7 & 19.59 & 0.48 \\
\hline 9. & Pod yield per plant (g) & $25.15-128.33$ & $61.11 \pm 9.044$ & 42.41 & 33.79 & 63.5 & 55.45 & 33.89 \\
\hline 10. & Pod yield (kg) & $1.01-5.13$ & $2.45 \pm 0.362$ & 41.75 & 33.02 & 62.6 & 53.38 & 1.32 \\
\hline 11. & Number of seeds per pod & $6.67-9.00$ & $7.07 \pm 0.338$ & 12.57 & 9.73 & 60.0 & 16.12 & 1.14 \\
\hline 12. & Pods length (cm) & $6.74-10.45$ & $8.50 \pm 0.212$ & 12.21 & 11.42 & 87.5 & 22.0 & 1.87 \\
\hline 13. & Number of cluster per plant & $4.13-21.93$ & $13.64 \pm 2.200$ & 38.22 & 26.10 & 46.6 & 36.73 & 5.01 \\
\hline 14. & $50 \%$ germination & $11.0-24.67$ & $16.32 \pm 1.171$ & 24.70 & 21.35 & 74.7 & 37.99 & 6.20 \\
\hline 15 & Number of node per plant & $10.33-22.40$ & $18.35 \pm 1.330$ & 18.40 & 13.46 & 53.5 & 20.27 & 3.72 \\
\hline 16 & Internode length $(\mathrm{cm})$ & $5.88-14.33$ & $8.87 \pm 0.709$ & 24.51 & 20.23 & 68.2 & 34.49 & 3.06 \\
\hline 17 & Days to harvesting maturity & $120.0-182.0$ & $151.0 \pm 1.693$ & 11.21 & 11.42 & 97.0 & 22.39 & 33.83 \\
\hline
\end{tabular}


In the present investigation, the estimates of heritability (broad sense) were and varied from $32.7 \%$ to $97.00 \%$ for different characters under studies found high for the characters for days to maturity, days to $50 \%$ flowering, pod length, plant height, 100 seed weight, days to $50 \%$ germination, internode length, pod yield per plant, pod yield per plot and number of seed per pod whereas for and harvest index, number of node per plant, number of cluster per plant, dry matter content and number of branch per plant moderate heritability was recorded.

Similar results for different characters have also been reported by Kosev et al., (2015). Genetic advance a measure of genetic gain under selection as per cent of population mean was low to high for various characters studied in the present experiment. The range was from $0.029 \%$ to $70.82 \%$. It was found high for the characters viz. plant height, pod yield per plant, pod yield per plot, number of pods per plant, days to $50 \%$ germination, number of cluster per plant, internode length, 100 seed weight, harvest index, days to maturity and number of node per plant whereas, moderate genetic gain was recorded for number of branch per plant, dry matter content and shelling percentage. Results corroborated with the findings of Sureja and Sharma (2000). In the present investigation, High heritability coupled with high genetic advance as percent of mean were observed for plant height, pod yield per plant and pod yield per plot. Estimate of GCV was also high for these traits indicating presence of additive gene effects suggesting more scope of selection for these traits. Number of seed per pod, pod length, internode length and 50\% germination showed higher heritability along with moderate genetic advance as percent of mean, which indicated that these characters are under the control of additive genes and are more reliable for effective selection similar result were reported by Kumar et al., (2004)

\section{Acknowledgments}

The author would like to heartiest thanks to all faculty member for given their valuable suggestions and guidance with their scientific acumen during the investigation and manuscript preparation.

\section{References}

Duke, J. A. 1981. Hand book of legumes of world economic importance. Plenum Press, New York. pp. 199-265.

Gomez, K. A. and Gomez, A. A. 1983. Statistical procedures for agricultural research. John Wiley and Sons Inc., New York. p. 357-427.

Gritton, E. T. 1980. Field Pea. In: Fehr, W. R. and Hadley, H. H. Hybridization of Crop Plants. American Society of Agronomy, Inc., and Crop Science Society of America, Inc., Wisconsin, USA. pp. 347-356.

Kosev, V. I. 2015. Multivariate analysis of spring field pea genotypes. BanatsJ. biotech., 6(11): 23-29.

Kumar, P., Partap, P. S. and Rana, M. K. 2004. Correlation studies in garden pea (Pisum sativum L.). Haryana J. Hort. Sci., 33 (3/4): 243-245.

Mehta, S., Kohli, U. K., Mehta, D. and Kumar, D. 2005. Genetic variability studies in pea (Pisum sativum L.). Haryana J. Hort. Sci., 34 (1/2): 140-141.

Nisar, M., Ghafoor, A. and Khan, M. 2011. Phenotypic variation in the agronomic and morphological traits of (Pisum sativum L.) germplasm obtained from different parts of the world. Russian J. Genetics, 47: 19-25.

Rai, M., Verma, A., Kumar, R. and Vishwanath. 2006. Multivariate genetic analysis of pea (Pisum sativum L.). Veg. Sci., 33 (2): 149-154.

Saxesena, R. R., Vidyakar, V., Vishwakarma, M. K., Yadav, P. S., Meena, M. L. and 
Lal, G. M. 2014. Genetic variability and heritability analysis for some quantitative traits in field pea (Pisum sativum L.). The Bioscan, 9(2): 895898.
Sureja, A. K. and Sharma, R. R. 2000. Genetic variability and heritability studies in garden pea (Pisum sativum L.) Indian J. Hort., 57(3):243-247.

\section{How to cite this article:}

Kumar Singh, A., A. Paliwal, S. Chandra Pant, P. Bahuguna, A. Bahadur and Bhalla, R. 2018. Estimation of Genetic Architecture in Agro-Morphological Traits of Garden Pea in Mid Hill Region of Uttarakhand, India. Int.J.Curr.Microbiol.App.Sci. 7(08): 3292-3298. doi: https://doi.org/10.20546/ijcmas.2018.708.351 